\title{
PENGARUH TINGKAT KEMATANGAN DAN KADAR GULA TERHADAP MANISAN KERING SAWO
}

\author{
Irzam Mirza, S.TP ${ }^{(1)}$ dan Rifni Novitasari, S.TP., MP ${ }^{(2)}$ \\ (1)Alumni Teknologi Pangan Faperta UNISI \\ (2) Dosen Teknologi Pangan Faperta UNISI
}

\begin{abstract}
Abstrak
Penelitian dengan judul "Pengaruh Tingkat Kematangan dan Kadar Gula terhadap Manisan Sawo yang Dihasilkan", bertujuan untuk mengetahui kadr air, kadar sukrosa dan kadar vitamin C. Penelitian ini menggunkan rancangan acak lengkap (RAL) factorial. Dengan faktor pertama (A) adalah tingkat kematangan buah yang terdiri dari dua perlakuan dan factor kedua (B) adalah kadar gula yang terdiri dari tiga perlakuan kemudian dengan tiga kali ulangan dan diperoleh pola perlakuan $2 \times 3 \times 3$ sehingga didapat 18 unit percobaan. Factor pertama disimbulkan dengan A1 (Matang) dan A2 (Tua) dan factor kedua disimbolkan dengan B1 (Kadar Gula 30\%), B2 (Kadar Gula 40\%) dan B3 (Kadar Gula 50\%).

Perlakuan dengan hasil terbaik adalah perlakuan $\left(\mathrm{A}_{1} \mathrm{~B}_{1}\right)$ sawo matang dan kadar gula 30\%. Dengan hasil pengamatan kadar sukrosa $63.38 \%$, kadar air 21,13\% dan kadar vitamin C 0,35\%. Kombinasi perlakuan ini secara organoleptik juga disukai oleh panelis, dimana warna manisan sawo tersebut coklat kekuningan, rasanya tidak terlalu manis dan tekstur yang dihasilkan lunak sedikit keras dimana nilai warna $(2,55)$, tekstur $(2,40)$ dan rasa $(2,35)$.
\end{abstract}

Kata kunci : Sawo, manisan, kadar gula

\section{PENDAHULUAN}

Buah sawo merupakan jenis buah buahan yang banyak mengandung asam ascorbat (vitamin C) dan asam folat yang sangat berperan dalam proses metabolisme dan pembentukan sel darah merah bagi yang mengkonsumsinya. Namun, karena kurangnya penganekaragaman cara pengolahannya buah sawo menjadi kurang diperhatikan terutama di Indragiri Hilir. Padahal dilihat dari letak geografis tanaman ini bisa tumbuh dan berkembang dengan baik, pertumbuhan jumlah produksi buah sawo meningkat tiap tahunnya, berdasarkan data Badan Pusat Statistik (BPS) Indragiri Hilir produksi sawo tahun 2009 berjumlah 214 ton per tahun,

2010 berjumlah 419 ton per tahun dan pada tahun 2011 berjumlah 490 ton per tahun (Novianto, 2012).

Sawo adalah salah satu buah yang memiliki daging buah yang lunak sehingga mudah mengalami kerusakan secara mekanis, fisiologis, kimia dan mikrobiologis. Untuk menghindari kerusakan tersebut dan untuk memperpanjang umur simpan maka sebaiknya sawo diolah menjadi berbagai jenis produk olahan. Selain itu juga untuk pengembangan agroindustri, proses pengolahan pascapanen buah sawo sangat potensial untuk dikembangkan. Dengan berkembangnya ilmu pengetahuan dan teknologi, saat ini terdapat berbagai teknologi proses pengolahan sawo menjadi aneka produk 
pangan antara lain, manisan, dodol, keripik, sari buah dan selai (Aryati dan Napitupulu, 2010).

Manisan sawo adalah buah sawo yang diawetkan dengan gula. Tujuan pemberian gula dengan kadar yang tinggi selain untuk memberikan rasa manis, juga untuk mencegah tumbuhnya mikroorganisme yaitu jamur dan kapang juga mempertahankan nilai gizi, seperti dijelaskan diatas buah sawo memiliki daging buah yang lunak, sehingga dalam proses pembuatanya dapat menggunakan teknik pembuatan manisan. Permasalahan yang terjadi dalam proses pembuatan manisan adalah tingkat kematangan buah yang mempengaruhi kadar manisan dari buah sawo sebagai bahan baku, sehingga mempengaruhi banyaknya gula yang dibutuhkan untuk mencapai kadar gula tertentu dalam pembuatan manisan ini sehingga diminati oleh konsumen (Haryadi, 2001).

\section{Rumusan masalah}

Sawo adalah salah satu buah yang memiliki daging buah yang lunak sehingga mudah mengalami kerusakan secara mekanis, fisiologis, kimia dan mikrobiologis. Dengan berkembangnya ilmu pengetahuan dan teknologi, saat ini terdapat berbagai teknologi proses pengolahan sawo menjadi aneka produk pangan antara lain, manisan, dodol, keripik, sari buah dan selai (Aryati dan Napitupulu, 2010).

Salah satu cara untuk membuat manisan sawo tersebut terasa nikmat diperlukan keseimbangan komposisi bahan bahan pembuatan terutama dosis gula dan tingkat kematangan buah. Sehingga kualitas manisan dapat dijaga kualitasnya dan tentunya akan meningkatkan produsen buah sawo (Ratule, 1999).
Berdasarkan uraian diatas penulis telah mengadakan penelitian dengan judul : "Tingkat Kematangan dan Kadar Gula terhadap Manisan Sawo yang dihasilkan".

\section{Tujuan}

Adapun tujuan dari penelitian ini adalah sebagai berikut:

1. Untuk mengetahui tingkat kematangan dan penambahan gula yang tepat dalam menghasilkan manisan sawo.

2. Untuk mengetahui korelasi antara analisis tingkat kematangan dan kadar gula terhadap kualitas manisan sawo yang dihasilkan.

\section{Manfaat Penelitian}

Adapun manfaat dari penelitian ini adalah :

1. Membantu petani sawo jika terjadi penumpukan produksi, sehingga buah sawo dapat diperpanjang masa simpannya.

2. Untuk memberikan pengetahuan tentang teknologi tepat guna dan pengolahan sumber daya alam yang melimpah sehingga selain bertujuan mengawetkan juga mendatangkan nilai tambah dalam menghasilkan penganekaragaman pada buah sawo.

\section{METODOLOGI PENELITIAN}

\section{Bahan}

Bahan yang digunakan dalam penelitian ini adalah buah sawo yang diperoleh langsung dari petani, gula pasir, air, asam sitrat, untuk uji pengamatan digunakan bahan $\mathrm{NaOH}$, $\mathrm{HCl}$, Fenolptalain, reagen, luff, KI, $\mathrm{H}_{2} \mathrm{SO}_{4}$, Thio, kanji, larutan Iod.

\section{Alat \\ Alat yang digunakan dalam penelitian ini adalah pisau, talenan,}


panci, baskom, kompor, sendok dan saringan, untuk pengamatan peralatan yang diperlukan labu ukur, gelas piala, pipet, kertas saring.

\section{Metode Penelitian}

Penelitian ini menggunakan Rancangan Acak Lengkap ( RAL ) faktorial. Factor pertama (A) adalah tingkat kematangan buah yang terdiri dari dua perlakuan dan factor kedua (B) adalah kadar gula yang terdiri dari tiga perlakuan kemudian dengan tiga kali ulangan dan diperoleh pola perlakuan $2 \times 3 \times 3$ sehingga didapat 18 unit percobaan.

Adapun faktor pertama yaitu untuk tingkat kematangan buah sawo dapat disimbolkan dengan:

$\mathrm{A}_{1} \quad$ : Matang

$\mathrm{A}_{2} \quad$ : Tua

Sedangkan untuk faktor kedua yaitu kadar gula yang ditambahkan dalam pembuatan manisan. Adapun untuk faktor ini dapat disimbolkan dengan lambang dengan:

$\mathrm{B}_{1} \quad$ : Kadar gula $30 \%$

$\mathrm{B}_{2} \quad$ : Kadar gula $40 \%$

$\mathrm{B}_{3} \quad$ : Kadar gula $50 \%$

Bila terdapat perbedaan nyata dalam setiap perlakuan maka analisa dapat dilanjutkan dengan uji BNT model rancangan yang digunakan adalah sebagai berikut:

$Y i j=\mu+A_{I}+B j+A_{I} B j+E_{I j}$

Dimana :

Yij : Hasil pengamatan penelitian pada perlakuan tingkat kadar gula kematangan buah sawo perlakuan pada posisi $_{-}$, dan perlakuan pada kadar-j.

$\mu$ : Nilai tengah umum

Ai : Pengaruh kematangan buah sawo pada ulangan ke-i,

$\mathrm{Bj}$ : Pengaruh kadar gula pada ulangan ke-j,
AiBj : Pengaruh interaksi perlakuan matangnya buah sawo pada ulangan ke-i dan perlakuan kadar gula pada ulangan ke-j,

Eij : Pengaruh sisa perlakuan matangnya buah sawo pada ulangan ke-i dan perlakuan kadar gula pada ulangan ke-j.

\section{Pelaksanaan Penelitian}

Tahap proses pembuatan manisan sawo ini beracu pada pelaksanaan adapun tahap proses pengolahan tersebut adalah sebagai berikut:

1. Persiapan bahan sawo atau sortasi

Persiapan dalam penelitian ini adalah menyediakan buah sawo buah sawo yang dipilih adalah buah yang awal matang atau tua di pohon dan buah sawo masak peram dengan perbedaannya adalah ciri-ciri buah sawo masak di pohon adalah belum lembek saat ditekan, kulit buah agak keras, kulit berwarna cokelat muda, daging buah agak lembek, bila dipetik mudah terlepas dari tangkainya, serta bergetah relatif sedikit. Sedangkan cirri-ciri sawo masak peram terlihat dari warna kulit buah agak kusam, kulit buah agak liat.

\section{Pengupasan}

Buah sawo dikupas kulit luarnya dengan menggunakan pisau, agar kulit luar yang kesat bersih.

3. Pengirisan

Pengiris dilakukan sesuai dengan keinginan, semakin kecil dan tipis suatu ukuran makan akan semakin baik rasa yang didapat. Peda penelitan ini pengirisan dengan menggunakan ukuran.

4. Pencucian

Pencucian dilakuakan dengan air yang mengalir dengan tujuan untuk menghilangkan getah yang masih tersisa.

5. Perebusan

Sawo direbus pada air mendidih yang telah diberi gula sesuai dengan 
setiap perlakuan yang dibutuhkan selama 2 sampai 3 menit dengan suhu $100^{\circ}$ C. Selanjutnya menambahkan asam sitrat sebanyak $0,6 \%$, dan setelah mendidih api dimatikan.

\section{Penirisan}

Perebusan sawo diangkat dan ditiriskan. Untuk mengurangi jumlah air sisa dari proses perebusan dan pori-pori pada buah bias menyerap dengan baik pada proses perendaman.

\section{Perendaman}

Irisan sawo yang telah ditiriskan direndam dalam larutan gula selama 12 jam, dengan ukuran perbandingan air dan gula pasir yaitu $200 \mathrm{ml}$ air : $10 \mathrm{gr}$ gula pasir.
8. Penaburan Gula

Irisan sawo yang telah direndam diangkat dan ditaburi gula halus.

9. Pengeringan

Selanjutnya irisan sawo dikeringkan di bawah sinar matahari selama 3-4 hari sesuai dengan tingkat kekeringan 20$25 \%$.

\section{HASIL DAN PEMBAHASAN}

\section{Kadar Air}

Pada pengamatan kadar air manisan sawo berdasarkan analisis sidik ragamnya pengaruh interaksi perlakuan tingkat kematangan buah dan penambahan kadar gula terhadap kadar air manisan buah sawo berkisar 61.30$71.19 \%$ dan factor rata-rata perlakuan adalah $\mathrm{B}_{1} 63.72, \mathrm{~B}_{3} 66.25$ dan $\mathrm{B}_{2} 70.76$ hal tersebut dapat dilihat pada Tabel 1 .

Tabel 1. Faktor Tingkat Kematangan Buah Sawo Dengan Persentase Kadar Gula Yang Ditambahkan Terhadap Kadar Air Manisan Sawo.

\begin{tabular}{|c|c|c|c|}
\hline Perlakuan & $\begin{array}{l}\mathrm{B}_{1}(\text { Kadar } \\
\text { gula } 30 \%)\end{array}$ & $\begin{array}{l}\mathrm{B}_{2}(\text { Kadar } \\
\text { gula } 40 \%)\end{array}$ & $\begin{array}{c}\mathrm{B}_{3}(\text { Kadar } \\
\text { gula } 50 \%)\end{array}$ \\
\hline $\begin{array}{l}\mathrm{A}_{1} \text { Matang } \\
\mathrm{A}_{2} \text { Tua }\end{array}$ & $\begin{array}{l}63.38 \mathrm{~b} \\
64.05 \mathrm{~b}\end{array}$ & $\begin{array}{l}70.65 \mathrm{c} \\
70.86 \mathrm{~cd}\end{array}$ & $\begin{array}{l}71.19 \mathrm{~d} \\
61.30 \mathrm{a}\end{array}$ \\
\hline
\end{tabular}

Keterangan $: *$ Angka pada tiap lajur yang diikuti oleh huruf yang sama berbeda tidak nyata pada tingkat kepercayaaan 5\% menurut uji BNT.

Kadar air tertinggi diperoleh dari perlakuan $\mathrm{A}_{1} \mathrm{~B}_{3}$ (matang dan kadar gula $50 \%$ ) yaitu sebesar 71.19 , hal tersebut dikarenakan kadar air sawo yang matang tinggi sebesar $68.41 \%$ sehingga persentase gula yang ditambahkan tidak sesuai dengan berat bahan baku yang digunakan dan mengakibatkan kadar airnya tinggi. Hal ini disebabkan karena semakin besar gula yang ditambahkan maka kadar air semakin berkurang sehingga waktu yang dibutuhkan untuk mengeringkan manisan semakin cepat (Hercules, 1988). Menurut Buckle et al. (1987), gula mempunyai kemampuan untuk mengikat air yang ada dalam bahan pangan. Terjadinya ikatan hidrogen yang menyebabkan berkurangnya aktivitas air dalam bahan pangan tersebut.

Kadar air tertinggi buah sawo berdasarkan interaksi antar faktor terdapat pada perlakuan $\mathrm{A}_{1} \mathrm{~B}_{3}$ yaitu sebesar 71.19 Hal tersebut dikarenakan buah sawo yang matang kadar air sawo masih tinggi karena belum terjadi penguapan pada buah sawo dan buah masih berpengaruh terhadap penyerapan nutrisi pada pohonnya, sedangkan pada bauh sawo tua kadar air buah sawo 
sudah menurun selama proses pemeraman, karena terjadi proses penguapan kadar air oleh suhu lingkungan (Astawan, 2008).

Pengaruh interaksi perlakuan tingkat kematangan buah dan penambahan kadar gula terhadap kadar air manisan dapat dilihat pada Tabel 2.

Tabel 2. Interaksi Antar Faktor B Terhadap A

\begin{tabular}{|l|r|c|}
\hline Perlakuan & Rata-rata & Simbol \\
\hline $\mathrm{A}_{2} \mathrm{~B}_{3}$ & 61.30 & $\mathrm{~A}$ \\
$\mathrm{~A}_{1} \mathrm{~B}_{1}$ & 63.38 & $\mathrm{~b}$ \\
$\mathrm{~A}_{2} \mathrm{~B}_{1}$ & 64.05 & $\mathrm{~b}$ \\
$\mathrm{~A}_{1} \mathrm{~B}_{2}$ & 70.65 & $\mathrm{c}$ \\
$\mathrm{A}_{2} \mathrm{~B}_{2}$ & 70.86 & $\mathrm{c} \mathrm{d}$ \\
$\mathrm{A}_{1} \mathrm{~B}_{3}$ & 71.19 & $\mathrm{~d}$ \\
\hline
\end{tabular}

Keterangan : * Angka pada tiap lajur yang diikuti oleh huruf yang sama berbeda nyata pada tingkat kepercayaaan 5\% menurut uji BNT.

Gula mempunyai kemampuan untuk mengikat air yang ada dalam bahan pangan. Terjadinya ikatan hidrogen yang menyebabkan berkurangnya aktivitas air dalam bahan pangan. Semakin tinggi gula yang ditambahkan pada produk menunjukkan pada akhir pengeringan terlihat total padatan semakin meningkat kadar air semakin menurun (Buckle et al. 1987).

Kadar air yang rendah pada perlakuan $\quad \mathrm{A}_{2} \mathrm{~B}_{3}$ sebesar 61.30 . Penyimpanan buah sawo pada suhu dingin dan suhu kamar $\left(23^{\circ} \mathrm{C}\right)$ dapat mengurangi jumlah bobot buah. Semakin lama penyimpanan yang dilakukan pada suhu kamar maka bobot buah akan banyak yang hilang. Hal ini dikarenakan buah kontak langsung dengan udara bebas, sehingga menyebabkan air yang terdapat pada buah lebih cepat menguap (Nuraisyah, 2012).

Penurunan kadar air juga bisa disebabkan oleh proses pengeringan yang melibatkan panas sehingga penguapan air terjadi. Menurut (Ponting et al, 1966), proses dehidrasi osmosis akibat perendaman dalam larutan gula mengakibatkan pengeluaran sejumlah air dari buah-buahan. Penambahan gula dapat menyebabkan peningkatan persentase total padatan meningkat sedangkan persentase air menurun. Penurunan kadar air terlihat dengan semakin besarnya gula yang ditambahkan. Lebih lanjut Syarief dan Halid (1993) menambahkan bahwa gula yang larut menyebabkan tekanan uap yang lebih rendah akan menyebabkan air lebih mudah menguap dari bahan yang dikeringkan.

\section{Kadar Gula (Sukrosa)}

Dari hasil analisa sidik ragam kombinasi perlakuan pada buah sawo masak peram dan masak panen di pohon dengan penambahan kadar gula 30\%, 40\% dan $50 \%$. Maka diketahui bahwa kombinasi tersebut berpengaruh terhadap sukrosa manisan sawo pada Tabel 3. 
Tabel 3. Interaksi Antar Faktor B Terhadap A

\begin{tabular}{|l|r|l|}
\hline \multicolumn{1}{|c|}{ Perlakuan } & \multicolumn{1}{c|}{ Rimbol } \\
\hline $\mathrm{A}_{1} \mathrm{~B}_{2}$ & 26.63 & $\mathrm{~A}$ \\
$\mathrm{~A}_{2} \mathrm{~B}_{2}$ & 28.59 & $\mathrm{a}$ \\
$\mathrm{A}_{2} \mathrm{~B}_{1}$ & 31.08 & $\mathrm{~b}$ \\
$\mathrm{~A}_{2} \mathrm{~B}_{3}$ & 33.62 & $\mathrm{c}$ \\
$\mathrm{A}_{1} \mathrm{~B}_{1}$ & 35.91 & $\mathrm{c} \mathrm{d}$ \\
$\mathrm{A}_{1} \mathrm{~B}_{3}$ & 36.48 & $\mathrm{~d}$ \\
\hline
\end{tabular}

Keterangan : * Angka pada tiap lajur yang diikuti oleh huruf yang sama berbeda tidak nyata pada tingkat kepercayaaan 5\% menurut uji BNT.

Dari data diatas menunjukkan bahwa interaksi tingkat kematangan buah dan kadar gula berkisar $93.2 \%$ dan memberikan pengaruh yang berbeda tidak nyata terhadap kadar gula (sukrosa) manisan yang dihasilkan. Kadar sukrosa manisan tertinggi diperoleh dari perlakuan $\mathrm{A}_{1} \mathrm{~B}_{3}$ (matang dan kadar gula $50 \%$ ) yaitu 36.48, kadar sukrosa manisan terendah diperoleh dari perlakuan $\mathrm{A}_{1} \mathrm{~B}_{2}$ (sawo matang dan kadar gula $40 \%$ ) yaitu 26.63. Selama proses pemanasan sebagian sukrosa atau gula terurai menjadi glukosa dan fruktosa karena kelarutan glukosa dan fruktosa sangat besar (Winarno, 1997). Sifat ini menunjukkan semakin banyak gula yang ditambahkan jumlah sukrosa semakin besar dan rasa manis semakin tinggi. Pada larutan gula yang tinggi akan menyebabkan total gula pada bahan meningkat. Selain itu menurut Astawan (2008) buah sawo yang masak di pohon lebih manis dibandingkan dengan buah yang masak diperam, sehingga kemanisan buah sawo juga mempengaruhi kadar gula manisan sawo pada perlakuan A1B3.

Berdasarkan standar mutu manisan (SNI 01-3710-1995) kadar sukrosa manisan minimum $40 \%$, dan kadar sukrosa pada perlakuan $\mathrm{A}_{1} \mathrm{~B}_{1}$, $\mathrm{A}_{1} \mathrm{~B}_{2}, \quad \mathrm{~A}_{1} \mathrm{~B}_{3}, \quad \mathrm{~A}_{2} \mathrm{~B}_{1}, \quad \mathrm{~A}_{2} \mathrm{~B}_{2}, \mathrm{~A}_{2} \mathrm{~B}_{3}$ yang berkisar antara $79.90 \%$ - $109.44 \%$ sehingga manisan yang dihasilkan memenuhi standar.

\section{Kadar Vitamin C}

Pengaruh tingkat kematangan buah terhadap vitamin $\mathrm{C}$ manisan buah sawo berkisar $0.67 \%-0.77 \%$ hal tersebut dapat dilihat pada Tabel 4.

Kadar vitamin $\mathrm{C}$ manisan dengan perlakuan kadar gula berkisar antara $0.55 \%-0.91 \%$.

Tabel 8. Rata-Rata Kadar Vitamin C Manisan Sawo Berdasarkan Interaksi Perlakuan Tingkat Kematangan dan Kadar Gula.

\begin{tabular}{|l|c|c|c|}
\hline \multicolumn{1}{|c|}{ Perlakuan } & $\begin{array}{c}\mathrm{B}_{1} \text { (Kadar } \\
\text { gula } 30 \%)\end{array}$ & $\begin{array}{c}\mathrm{B}_{2} \text { (Kadar } \\
\text { gula } 40 \%)\end{array}$ & $\begin{array}{c}\mathrm{B}_{3} \text { (Kadar gula } \\
50 \%)\end{array}$ \\
\hline $\mathrm{A}_{1}$ (matang) & $1.06 \mathrm{a}$ & $0.53 \mathrm{a}$ & $0.73 \mathrm{a}$ \\
$\mathrm{A}_{2}$ (tua) & $0.76 \mathrm{a}$ & $0.56 \mathrm{a}$ & $0.69 \mathrm{a}$ \\
\hline
\end{tabular}

Keterangan : * Angka pada tiap lajur yang diikuti oleh huruf yang sama berbeda tidak nyata pada tingkat kepercayaaan 5\% menurut uji BNT.

Data diatas menunjukkan bahwa interaksi tingkat kematangan buah dan kadar gula memberikan pengaruh yang berbeda tidak nyata terhadap kadar 
vitamin C manisan yang dihasilkan. Kadar vitamin $\mathrm{C}$ manisan tertinggi diperoleh dari perlakuan $\mathrm{A}_{1} \mathrm{~B}_{1}$ (matang dan kadar gula $30 \%$ ) yaitu $1.06 \%$, sedangkan kadar vitamin $\mathrm{C}$ manisan terendah diperoleh dari perlakuan $\mathrm{A}_{1} \mathrm{~B}_{2}$ (matang dan kadar gula 40\%) yaitu $0.53 \%$.

Berdasarkan hasil penelitian diketahui bahwa kandungan vitamin $\mathrm{C}$ dalam manisan sawo lebih kecil dibandingkan kandungan vitamin $\mathrm{C}$ dalam buah segarnya sebesar 21.00 mg/100 gr bahan. Kecilnya kandungan vitamin $\mathrm{C}$ dalam manisan sawo dipengaruhi oleh buah yang menjadi sumber vitamin $\mathrm{C}$ (asam askorbat) dan kemungkinan terjadinya degradasi vitamin $\mathrm{C}$ selama pengolahan.

Buah sawo yang digunakan dalam pembuatan manisan persentasenya sedikit. Hal ini menyebabkan asupan vitamin $\mathrm{C}$ juga sangat terbatas, sehingga kandungan vitamin $\mathrm{C}$ dalam produk akhir juga sedikit. Selain itu, pemanasan selama pengolahan dapat menyebabkan terjadinya degradasi vitamin $\mathrm{C}$. Hal ini disebabkan panas dapat mempercepat terjadinya oksidasi vitamin C. Menurut Winarno (1997), vitamin C mudah teroksidasi dan proses tersebut dipercepat oleh panas, sinar, alkali, enzim, oksidator serta oleh katalis tembaga dan besi. Pada proses pengolahan pangan, kehilangan vitamin $\mathrm{C}$ akibat reaksi enzimatis jumlahnya sangat sedikit, sedangkan reaksi non enzimatis menjadi penyebab utama hilangnya vitamin $\mathrm{C}$.

Vitamin $\mathrm{C}$ tergolong vitamin yang mudah larut dalam air. Vitamin $\mathrm{C}$ atau asam L-askorbat adalah lakton, yaitu ester dalam asam hidroksikarboksilat dan diberi ciri oleh gugus enadiol yang menjadikan senyawa pereduksi yang kuat. Asam L-askorbat mudah teroksidasi secara reversibel menjadi asam Ldehidroaskorbat yang masih mempunyai keaktifan sebagai vitamin C (Deman, 1997). Asam dehidroaskorbat secara kimia sangat labil dan dapat mengalami perubahan lebih lanjut menjadi asam Ldiketogulonat yang tidak memiliki keaktifan vitamin C. Asam Ldiketogulonat yang teroksidasi akan membentuk asam oksalat dan asam Ltreonat (Winarno, 1997).

\section{KESIMPULAN DAN SARAN}

\section{Kesimpulan}

Kesimpulan yang diperoleh setelah melakukan penelitian ini adalah sebagai berikut :

1. Kombinasi perlakuan sawo matang dan kadar gula $30 \%\left(\mathrm{~A}_{1} \mathrm{~B}_{1}\right)$ adalah perlakuan yang terbaik untuk manisan sawo, dimana kadar sukrosa $63.38 \%$, kadar air $21.13 \%$ dan kadar vitamin C $0.35 \%$. Kombinasi perlakuan ini secara organoleptik juga disukai oleh panelis, dimana warna manisan sawo tersebut coklat kekuningan, rasanya tidak terlalu manis dan tesktur yang dihasilkan lunak sedikit keras dimana nilai warna (2.55), tekstur (2.40) dan rasa (2.35).

2. Kombinasi tingkat kematangan dan kadar gula berpengaruh terhadap kadar air manisan sawo yang dihasilkan tetapi berbeda tidak nyata terhadap kadar sukrosa dan kadar vitamin $\mathrm{C}$ manisan sawo yang dihasilkan.

\section{Saran}

Untuk penelitian selanjutnya, hendaknya dilakukan upaya untuk menentukan umur simpan manisan sawo ataupun pengemas hermetis yang kedap air. 


\section{DAFTAR PUSTAKA}

AOAC Assosiation of Official Analitical Chermist, 2005. Official Method of Analysis of The Association of Official Analytical of Chemist. Arllington: The Association of Official Analytical Chemist, Inc.

Apriyantono, Anton. 1989. Petunjuk Laboratorium Analisa Pangan. IPB Press. Bogor.

Astawan, M. 2008. Manfaat Sawo dan Pengolahannya. IPB. Bogor.

Badan Standardisasi Nasional (BSN). 1995. Standar Nasional Indonesia. SNI.01-3710-1995 tentang Buah Kering. BSN. Jakarta.

Baedowi. 1980. Pengetahuan bahan hasil pertanian (PBHP). Direktorat Dikmenjur. Jakarta.

Buckle, R.A.Edwars, G.A. Fleet, Wootton, M. 2007. Ilmu Pangan. Universitas Indonesia,Jakarta.

Ditinur, 2009. Cara Membuat Manisan Buah. Aneka Karya. Jakarta.

Fatah, M dan Bachtiar. 2004. Membuat Aneka Manisan Buah. Agromedia Pustaka. Jakarta.

Hariyadi, P. 2001. Tekno Pangan dan Agroindustri.Jurusan Teknologi Pangan dan Gizi, FakultasTeknologi Pertanian IPB Bogor. Volume 1, Nomor 1-12.

Haryati, V dan Napitupulu, B. 2010. Pengolahan Buah Sawo Secara Sederhana Untuk Mendukung Agroindustri Hortikultura. Badan Penelitian dan

Pengembangan.Sumatera Utara.

Moenarti, M. 2003. Manisan Buah. Gramedia Pustaka Utama. Jakarta.

Murniati.2004. Teknologi Tepat Guna di Bidang Pertanian dan Industri Kecil. Badan Penelitian dan
Pengembangan (BPP) Provinsi

Sumatra Utara. Medan.

Novianto, E. 2012. Data Statistik Pertanian. Kabupaten Indragiri Hilir.

Nurjanah, N. 2007. Peluang Usaha Manisan Buah dan Sayuran. Penebar Swadaya. Jakarta.

Ponting, J.D., G.G. Watters, R.R. Forrey, R. Jackson and W.L. Stanley. 1966. Ostomic Dehydration of Fruits. J. Food. Tech. 20 (10) : 125-128

Raharjo, B. 2000. Penentuan Kematangan Buah Berdasarkan Pelacakan Parameter Tumbukan. Lembaga penelitian UGM. Yogyakarta

Sari, A, T. 2012. Morfologi Tumbuhan Sawo Kecil. Jurusan Biologi Fakultas Sains dan Matematika. Universitas Diponegoro. Semarang.

Satuhu, S. 1994. Penanganan dan Pengolahan Buah.Swadaya. Jakarta.

Shirotsuya. 2008. Manisan Buah Sawo Kering. Multi play com / Recipes.Diakses 2012.

SNI 01-2891-1992. Cara uji makanan dan minuman. Badan Standarisasi Nasional. Jakarta.

Soekarto, S, T. 1985. Organoleptik Penilaian Untuk Industri Pangan dan Hasil Pertanian. Bharatara Karya Aksara. Jakarta.

Sudarmadji, S. Haryono, B. Suhardi. 1984. Analisa Bahan Makanan dan Pertanian. Liberty. Yogyakarta.

Syarief R dan Halid. 1993. Teknologi Penyimpanan Pangan. Arcan. Jakarta.

Winarno.1997. Kimia Pangan dan Gizi. Gramedia Pustaka Utama. Jakarta. 